\title{
EVOLUÇÃO HISTÓRICO-LEGAL DO REGIME DE GESTÃO E ADMINISTRAÇÃO DA ESCOLA PÚBLICA PORTUGUESA: DOS DESCOBRIMENTOS ATÉ À PRIMEIRA REPÚBLICA
}

\author{
Maria João de Carvalho ${ }^{1}$ \\ Teresa Soares ${ }^{2}$
}

\section{RESUMO}

Sabemos que a escola assumiu diferentes concretizações sócio-históricas, que vão desde a sua realização inicial como instituição familiar passando pela escola enquanto instituição religiosa para finalmente se transformar em instituição estatal (Ciscar, Uría, 1988). É por este caminho evolutivo que se pretende fazer uma breve incursão, no pressuposto de que o passado sempre explica o presente e nos aponta rumos para o futuro. Procederemos, assim, a uma retrospetiva histórica e legal que nos permita conhecer a evolução dos modelos de gestão e administração, em particular dos órgãos diretivos, da escola pública portuguesa desde os descobrimentos até à $1^{\circ}$ República.

Palavras-chave: reformas, gestão da organização, corpos diretivos, reitor.

\footnotetext{
${ }^{1}$ Universidade de Trás-os-Montes e Alto Douro (Utad), Portugal.
}

${ }^{2}$ Universidade de Trás-os-Montes e Alto Douro (Utad), Portugal. 


\title{
EVOLUCIÓN HISTÓRICA Y LEGAL DEL RÉGIMEN Y DE ADMINISTRACIÓN DE LA ESCUELA PORTUGUESA: DESDE LOS DESCUBRIMIENTOS HASTA LA PRIMERA REPÚBLICA
}

\author{
RESUMEN \\ primera República.

\section{HISTORICAL AND LEGAL EVOLUTION OF THE MANAGEMENT AND ADMINISTRATION SYSTEM OF THE PORTUGUESE PUBLIC SCHOOL: FROM THE AGE OF DISCOVERIES TO THE FIRST REPUBLIC}

Sabemos que la escuela ha asumido distintas concretizaciones socio-históricas, empezando como institución familiar, siguiendo como institución religiosa para finalmente transformarse en una institución estadual (Ciscar, Uría, 1988). Es por este camino evolutivo que pretendemos hacer una breve incursión, desde el punto de vista de que el pasado siempre explica el presente y nos apunta rumbos para el futuro. Haremos, así, una retrospectiva histórica y legal que nos permitirá conocer la evolución de los modelos de gestión y administración, en particular de los órganos de dirección, de la escuela pública portuguesa desde los descubrimientos hasta la

Palabras clave: reformas, gestión de la organización, cuerpos de dirección, director.

\begin{abstract}
We know that the school has assumed different sociological and historical perspectives, ranging from its early idea as a family entity to a school as a religious institution, to finally transform itself into a state institution (Ciscar, Uría, 1988). It is through this path of evolution that a brief incursion is intended, in the assumption that the past always explains the present and points out the future. We shall, thus, proceed to an historical and legal review, which will allow us to know the evolution of the management and administration systems, in particular of the governing structures, of the Portuguese Public School from the Age of Discoveries to the First Republic.
\end{abstract}

Keywords: reforms, organization management, governing structures, rectors.

\section{EVOLUTION HISTORIQUE ET LÉGALE DU REGIME DE GESTION ET D'ADMINISTRATION DE L'ÉCOLE PUBLIQUE PORTUGAISE: DEPUIS LES DÉCOUVERTES JUSQU'À LA PREMIÈRE RÉPUBLIQUE}

RÉSUMÉ

Nous savons que l'école a assumé de différentes mises en place socio-historiques, allant de sa réalisation initiale comme institution familiale, à une école vue comme une institution religieuse et, enfin, se transformer en une institution d'état (Ciscar, Uría, 1988). C'est en ce chemin 
évolutif que nous prétendons faire une petite irruption, en admettant que le passé explique toujours le présent et nous montre des destinations vers l'avenir. Nous effectuerons, ainsi, une rétrospective historique et légale qui nous permettra de connaître l'évolution des modèles de gestion et d'administration, plus précisément des organes directeurs, de l'école portugaise depuis les découvertes jusqu'à la première république.

Mots-clés: réformes, gestion de l'organisation, corps des directeurs, directeur de l'école. 


\section{OS DESCOBRIMENTOS E O ADVENTO DA CULTURA RENASCENTISTA E HUMANISTA: IMPACTO DAS ORDENS RELIGIOSAS NO ENSINO}

O Renascimento e a cultura antropocêntrica marcam uma ruptura com a Idade Média e os ideais teocêntricos. O impacto faz-se sentir em todos os setores da sociedade, com incidência no ensino, retirando à escola o papel exclusivo na transmissão do saber.

Neste contexto, em Portugal, no reinado de D. João III, ocorreu uma reforma do ensino centrada no Mosteiro de Santa Cruz, em Coimbra, que ficou muito aquém do previsto, muito pela dificuldade de quebrar amarras com o pensamento escolástico e com a pedagogia medievais. Além disso, qualquer tentativa de modernização e de equiparação aos exemplos europeus esbarraria na parede erguida pela Igreja contra a Reforma que grassava pelos países do norte da Europa.

Em 1547, ainda por ação de D. João III, funda-se, em Coimbra, o Colégio das Artes que, a par das Escolas Gerais e dos conventos, se responsabilizava pelo ensino. Desta fundação se faz menção pela referência ao corpo diretivo e à hierarquia aí estabelecidos. O rei elegeu um principal do colégio e um subprincipal. Ao primeiro atribuí-lhe completa autoridade sobre os mestres, com poderes para os suspender ou substituir. Apenas o rei e o principal eram responsáveis pela gestão do colégio, estando este independente do reitor da Universidade.

A expansão da reforma protestante e a sua ação contaminadora abalou profundamente o status quo, levando ao Concílio de Trento (1545-1563). Em Portugal, erguiam-se vozes indignadas nos púlpitos das igrejas e nas cátedras das escolas. D. João III tomou conhecimento da nova Companhia de Jesus, fundada por Inácio de Loiola (1491-1556) e pensou em enviar missionários jesuítas para o Oriente em serviço de evangelização. Não tendo cumprido, pelo menos na totalidade, esta promessa, proporcionou-lhes um edifício em Lisboa e, 
mais tarde, em Coimbra, onde fundaram o Colégio de Jesus, a 2 de julho de 1542, com o objetivo de preparar futuros missionários. O primeiro reitor do colégio foi um jesuíta espanhol, Diogo Mirão. A ascendência e prosperidade dos jesuítas facilmente se comprovam pela incumbência de assegurarem o ensino das letras e da fé cristã ao príncipe D. João, então com nove anos. A sua expansão e influência no ensino ultrapassaram, certamente, as suas próprias expectativas, pois

o êxito surpreendente da actuação dos jesuítas nos locais em que se iam instalando fez-lhes considerar a conveniência de eles próprios criarem as suas escolas públicas, ou seja, escolas suas onde fosse permitida a frequência de estudantes não jesuítas, nas quais eles, jesuítas, fossem os mestres (CARVALHO, 1986, p. 292).

Em 1551, Inácio de Loiola manda criar o ensino público em várias cidades de Portugal, com incidência nas cidades de Lisboa e Évora, cumprindo um vasto plano de educação e de ensino com impacto em todos os lugares onde a Companhia se ia instalando. Como resultado, as escolas públicas com orientação pedagógica da Companhia de Jesus cresceram extraordinariamente, não só no continente e nos arquipélagos da Madeira e dos Açores mas, também, nos territórios ocupados no Oriente e em África.

Em termos de administração, o reitor, jesuíta nomeado pela própria Companhia, ocupava-se das tarefas de caráter pedagógico e didático, como a criação dos curricula, e elaborava e executava as normas de orientação e funcionamento dos Colégios. Em 1598, foi promulgado o Ratio Studiorum, documento de referência onde constavam as normas pedagógicas a serem seguidas por todas as escolas da Companhia e que estaria em vigor até 1832 .

Efetivamente, a insinuação dos jesuítas na corte, desenvolvendo estratégias de aproximação ao rei e seus próximos, permitiu-lhes dominar, em completa segurança, o ensino em Portugal, durante dois séculos, coexistindo, é certo, com um também crescente número de escolas particulares. Aliás, o 
monopólio da instrução pública é confirmado pela bula de Paulo V, publicada em 29 de maio de 1568, que impede o próprio rei de interferir na recente fundação da Universidade de Évora da responsabilidade dos jesuítas.

Todavia, a crescente procura do ensino e o mais que significativo aumento do número de alunos não pode ser associado simplesmente à influência apostólica dos jesuítas, mas entendido no contexto da excitação dos Descobrimentos, do interesse pelos negócios e da promoção do homem do Renascimento. Porém, é inegável que a Companhia de Jesus viu e usou o ensino como uma arma de influência e transformação social, capaz de moldar mentalidades e combater, à época, as heresias provenientes das crescentes contestações religiosas.

Mesmo a ocupação castelhana e a perda de independência no séc. XVII não abalaram o papel de relevo da Companhia de Jesus e da sua ação pedagógica na nação, o que se compreende pelo facto dos curricula não incluírem qualquer noção de pátria, aprendendo-se no reino o que se aprenderia em qualquer outra escola jesuítica da Europa.

Em síntese, constata-se que, particularmente ao longo dos séculos XVI e XVII, a organização da instrução se manteve apanágio dos educadores religiosos, com destaque para as Ordens dos jesuítas, dos oratorianos e mesmo dos jansenistas (MARQUES, 1980). Assim, durante séculos, apenas uma minoria privilegiada tinha acesso a aulas de ler e escrever, ensinamentos transmitidos, a título particular, pela família, por precetores ou mestres em regime domiciliário e individual, em aulas coletivas em escolas clericais, ou, a título público, em colégios destinados ao ensino secundário e nas Universidades de Coimbra ou Évora. 


\section{PROTAGONISTAS EDUCATIVOS DURANTE A MONARQUIA ABSOLUTISTA E O ILUMINISMO - A REFORMA POMBALINA}

É no século XVIII que a Companhia de Jesus enfrenta a concorrência de outra ordem religiosa, a da Congregação do Oratório, com uma ação pedagógica modernizada relativamente às doutrinas filosóficas e ideológicas lecionadas, e que contava com o apoio do rei, muitas vezes, em prejuízo dos jesuítas, que tinham em Luís António Verney o seu grande opositor. O caminho apontado era uma reforma no ensino a todos os níveis, com incidência nos métodos pedagógicos, nos compêndios, nos programas, na própria preparação dos mestres. Esta reforma teria impacto não só nas escolas baixas, que corresponderiam, na atualidade, às escolas dos $1 .^{\circ}, 2 .^{\circ}$ e $3 .^{\circ}$ ciclos do ensino básico e do ensino secundário, mas também nas escolas altas, correspondendo ao ensino superior. Neste contexto é impresso O Verdadeiro Método de Estudar, obra de referência do ensino em Portugal, que potencia a ação reformista do ensino, e que ilustra o pensamento modernista de Luís António Verney.

O sucessor de D. João V, o déspota esclarecido D. José, procurou adaptar as estruturas administrativas às exigências da época das "luzes", tomando medidas que, necessariamente, abalariam as forças e interesses instalados, nomeadamente dos nobres e da Companhia de Jesus. Nesta conjuntura, emerge uma figura incontornável na história do ensino em Portugal: Sebastião José de Carvalho e Melo, comummente conhecido como o Marquês de Pombal. Numa tentativa de modernizar o país, os seus vinte e sete anos de governo (1750-1777) foram pródigos em reformas nos setores vitais da sociedade portuguesa, incluindo o sistema educativo.

O ideário iluminista está bem patente no ímpeto reformador e visionário deste político, que "adiantando-se, nesse domínio, a quase todas as nações da Europa, criou um sistema de ensino estatal e laico" (GOMES, 1989, p. 7-8). Uma das medidas mais profundas prende-se, exatamente, com a laicização 
do ensino por força da expulsão dos jesuítas do reino. É o Alvará Régio de 28 de junho de 1759 que dá conta desta nova política consubstanciada na proibição explícita de os jesuítas exercerem o ensino, bem como na extinção de todas as classes e escolas a seu cargo em Portugal e restantes territórios coloniais, terminando, assim, com duzentos anos de atividade pedagógica ininterrupta. A crítica feroz denota-se pela imputação à Companhia de Jesus de responsabilidades no atraso cultural e científico do país.

A "geral reforma" do ensino, contendo em si o embrião do atual modelo centralizado, contempla também a criação da "Directoria Geral dos Estudos", departamento que esteve na origem do atual Ministério da Educação. Pela primeira vez, na história do ensino em Portugal, se institui uma entidade, subordinada ao poder vigente, responsável pela gestão e orientação do ensino elementar e médio. O Diretor-Geral era o responsável pelo cumprimento de toda a legislação referente ao ensino. A Carta Régia de 6 de julho de 1759 nomeia o prelado D. Thomaz de Almeida "Director dos Estudos" do Reino, sendo-lhe "todos os professores subordinados". A seu cargo ficava a nomeação e colocação dos professores de Gramática Latina, Grega, Hebraica e de Retórica, que deviam responder às "Instruções" metodológicas definidas para a sua lecionação. Deveria, ainda, nomear os comissários, responsáveis por regular, com o auxílio de governadores e bispos, o funcionamento das aulas, constando, ainda, das suas obrigações o envio de relatórios anuais ao rei. A Carta determina, ainda, que para cada bairro de Lisboa se estabelecesse um professor de Gramática Latina com "classe aberta e gratuita" ou, ainda, que para cada uma das vilas da Província se estabelecessem um ou dois professores da mesma disciplina, que seriam eleitos após um "rigoroso exame feito por Comissários delegados pelo Director-Geral”.

Aos docentes autorizados a ensinar eram concedidos os privilégios dos nobres, patenteados, por exemplo, nos "trezentos mil réis de ordenado [...] e mais cem mil réis para casas”, medida que pretendia aumentar o número de interessados no magistério. Todavia, no relatório de 23 de setembro de 1763, o 
Diretor-Geral queixa-se da falta de professores sentida em todo o país, já que os habitantes, vivendo pobremente, não dispunham de rendimentos capazes de pagar o salário ao mestre, pelo que não enviavam sequer os filhos para as escolas (CARVALHO, 1986).

A legislação coeva denota a preocupação de garantir o acesso ao ensino de todos os habitantes quer do reino quer dos territórios além-mar. O Alvará Régio de 17 de Agosto de 1758 estabelece em cada povoação do Pará e Maranhão, no Brasil, duas escolas públicas, referindo-se aos seus responsáveis como "um mestre e uma mestra, que devem ser pessoas dotadas de bons costumes, prudência e capacidade, de sorte que possam desempenhar as importantes obrigações de seus empregos". Também no Reino se inova, por exemplo, com a criação da "Aula de Comércio", presidida por "um ou dois mestres, dos mais peritos que se conhecerem, determinando-lhes ordenados competentes e obrigações que são próprias de tão importante emprego".

Não existindo referências concretas às 'obrigações', somos levados a crer que os mestres acumulariam as funções de gestão e lecionação, estando sujeitos ao cumprimento das diretivas emanadas da referida "Directoria Geral dos Estudos", que seria extinta em 1771, sendo transferida para a Real Mesa Censória "toda a administração e direcção dos Estudos das Escolas Menores destes Reinos e seus Domínios, incluindo nesta administração e direcção, não só o Real Colégio de Nobres, mas todos e quaisquer outros colégios e magistérios [...] para os estudos das primeiras idades" (GOMES, 1989, p. 14). À Real Mesa Censória cabia a responsabilidade de fiscalizar as escolas públicas e a de administrar completamente os Estudos Menores, não tendo, por isso, jurisdição sob a Universidade de Coimbra.

Os anos que se seguiram ao Alvará de 1759 são assinalados como o nascimento da escola pública em Portugal e territórios colonizados. Todavia, mesmo com a regulamentação minuciosa, que criava uma rede escolar pública padronizada, a reforma dos Estudos Menores sofreu, na sua primeira fase (1759 a 1772), sérias dificuldades de concretização, evidenciadas pelos problemas 
visíveis na educação dos cidadãos do reino.

Fruto de uma exposição sobre o estado do ensino em Portugal, em 3 de agosto de 1772, a Real Mesa Censória apresenta um plano para fazer frente ao "estrago causado nas Escolas Menores deste Reino pela negligencia e educação positivamente má dos jesuítas a que elas foram confiadas, e não se havendo reparado até o presente quanto era necessário". Adequando-se a um organismo estatal, a ação proposta sistematizava pioneiramente um quadro de Escolas Menores, abrangendo o continente, Ilhas e territórios colonizados em África, Ásia e América, com a sua localização exata e o número de mestres envolvidos. À época, coexistiam os termos "mestre", designando os que ensinavam a ler, escrever e contar e o termo "professores" para os restantes docentes das disciplinas de Humanidades, equivalente ao ensino secundário.

A Carta de Lei de 6 de novembro de 1772 reveste-se de grande importância por consagrar um sistema de ensino nacional e estatal, sistematizado e organizado, pese embora o facto de não abranger a totalidade da população (algo impraticável nas condições económicas e ideológicas do séc. XVIII) nem todos os graus de ensino. Além de instituir o ensino público, criar escolas e lugares de professores, definir métodos e matérias a ensinar, previa, ainda, no seu artigo 6, visitas às escolas, de quatro em quatro meses, por inspetores da Real Mesa Censória que tinham como função observar os progressos ou irregularidades, confirmar o exame das habilitações dos professores, colocá-los nas escolas e analisar os relatórios que cada um era obrigado a enviar sobre os discípulos a cargo. Todos os que exerciam a docência seguiam, assim, as diretrizes emanadas primeiro pela Diretoria-Geral e, depois de extinta, pela Real Mesa Censória. É também de referir que a reforma pombalina no ensino denuncia a morosidade estatal, já que, entre a expulsão da Companhia de Jesus até à apresentação do mapa das escolas menores, decorrem treze anos. Todavia, é inquestionável a ação pioneira do Marquês de Pombal, pois "foi ele quem, pela primeira vez na nossa história, planeou uma rede de escolas primárias públicas que, de certa maneira, faria a cobertura das 
principais povoações do País” (GOMES, 1989, p. 14-15).

A laicização do ensino representa, indubitavelmente, o primeiro passo para a concretização do controlo estatal sobre a educação, circunstância que só poderia ser efetivada tendo em conta as dimensões organizacionais do processo educativo, isto é, através da implantação de um novo tipo organizacional, concretizado na escola pública. A partir deste momento, o Estado passa a "controlar a educação, através de uma administração fortemente centralizada que, ao contrário de muitas escolas criadas pelo Marquês de Pombal, extintas poucos anos depois, permaneceria como um dos traços mais característicos da Administração Pública e da administração da educação em Portugal" (LIMA, 1998, p. 42).

A ideia da secularização do ensino encetada pelo ministro de D. José pode, todavia, ser questionada, já que se confunde, não raras vezes, a Igreja com a Companhia de Jesus. Com efeito,

\footnotetext{
Pombal retirou o ensino das mãos da Companhia de Jesus mas a Igreja continuou a dominar superiormente o ensino. As autoridades pedagógicas, ao mais alto escalão, eram, em grande parte, eclesiásticas, como o foi D. Tomás de Almeida, Director-Geral dos Estudos, como o foram a chefia e os deputados da Real Mesa Censória, como o foram o novo reitor da Universidade de Coimbra, D. Francisco de Lemos, membro da Junta de Providência Literária, e outros membros dela, como Cenáculo. Muitos professores de Latim da nova vaga eram sacerdotes, e as várias Ordens religiosas, como a dos Oratorianos, colaboraram, com os seus mestres, nas reformas do ensino (CARVALHO, 1986, p. 467).
}

Comprova-se, assim, que as medidas pombalinas não eliminaram, por completo, a ação pedagógica da Igreja, que permaneceu ativa quer através de ordens religiosas que não tinham caído em desgraça, como os Oratorianos, quer através da ação de frades e sacerdotes disseminados por todo o território.

Em termos gerais, poderemos destacar os já referidos Alvará de 28 de Junho de 1759, que institui o equivalente ao ensino secundário, e a Carta de Lei 
de 6 de Novembro de 1772, que institui a instrução primária oficial. Muito embora estes documentos não pormenorizem o funcionamento das escolas, centram-se em "questões de acesso (de alunos e de professores), criação e localização de escolas, controlo público do ensino particular e doméstico (principalmente através de exames prévios aos professores particulares), regulamentação geral de horários lectivos mínimos, férias, procedimentos disciplinares, substituição de professores, etc. e, sobretudo, nos métodos de ensino" (LIMA, 1998, p. 43). A literatura da especialidade mantém-se frugal no que respeita à direção dos (poucos) estabelecimentos de ensino a funcionar em Portugal. Relativamente à direção dos colégios mantêm-se os cargos de reitor e vice-reitor, muito embora, no Colégio Real dos Nobres estes cargos, inicialmente exercidos por portugueses foram, mais tarde, da responsabilidade de estrangeiros, mais do agrado do Marquês de Pombal.

Com a morte do Marquês de Pombal, e após a subida ao trono de D. Maria I, a Igreja reassume o seu domínio, através da reforma decretada em 16 de agosto de 1779. Além das escolas espalhadas pelo território português continental, insular e ultramarino, registam-se, à época, aulas de estudos menores lecionadas em mosteiros, cujos mestres seriam membros das respetivas ordens e de estudos médios em conventos.

Recordemos que o primeiro passo para a criação de um organismo estatal responsável pela administração e orientação dos estudos fora tomado pelo Marquês de Pombal, aquando da criação da Direção-Geral de Estudos, em 1759, substituído, em 1771, pela Real Mesa Censória. A 21 de junho de 1787, D. Maria I extingue o último organismo e funda a Real Mesa da Comissão Geral sobre o Exame e Censura dos Livros com funções mais amplas de coordenação dos estudos Menores do reino e seus domínios, da inspeção do Real Colégio dos Nobres e da administração do Subsídio Literário.

Sucedem-se anos de rutura e de grandes movimentações sociais, com expoente máximo na Revolução Francesa. Em Portugal, D. Maria I vive aterrorizada com os eventos que se abatem sobre as famílias reais europeias, 
temendo o contágio dos ideais revolucionários. Em termos de ensino, avançamos até à Carta Régia de 17 de Dezembro de 1794, já com D. João VI no trono, que extingue a Real Mesa, substituindo-a pela Junta da Diretoria-Geral dos Estudos e Escolas destes Reinos, estabelecida na Universidade de Coimbra e composta por um presidente (o reitor), seis deputados e um secretário. Se nos territórios colonizados no Ultramar, os chamados Domínios, as escolas estavam a cargo dos governadores e bispos, no reino ficavam, agora, sob a alçada da Universidade. Apenas o Colégio dos Nobres ficava de fora, reservando-se a sua inspeção à Secretaria de Estado dos Negócios do Reino.

Conclui-se, assim, que é a partir de marcos históricos como o Iluminismo, a Revolução Francesa, o Liberalismo e a Revolução Industrial que a escola passou a ser um assunto do Estado, com medidas como a nacionalização das escolas e a criação de sistemas estatais de ensino, destacando-se, em Portugal, a reforma pombalina enquanto plano de ação conducente ao sistema público de ensino. Sabe-se, também, que a sociedade portuguesa se debateu com dificuldades na transição entre o professor tradicional (padre, sacerdote, monge) para o mestre laico, recrutado em estratos sociais populares (por via dos seminários) ou burgueses (SERRÃO, 1981).

\section{GESTÃO E ADMINISTRAÇÃO ESCOLAR DURANTE O LIBERALISMO E MONARQUIA CONSTITUCIONAL - CONSELHO DO LICEU E REITOR (1836-1910)}

Os primórdios do séc. XIX, em Portugal, ficaram marcados por grandes convulsões políticas, fruto das invasões francesas e da fuga da família real e da corte para o Brasil (1807). Em termos de ensino, destaca-se a proliferação de Escolas Mútuas ${ }^{3}$ e do significativo número de Escolas Militares, dirigidas pelos

\footnotetext{
3 A designação advém da metodologia utilizada, o "método Lancaster" ou "método do ensino mútuo", que consistia em aproveitar os alunos mais competentes para ensinar os menos
} 
comandantes das várias unidades militares, granjeando grande sucesso e prestígio face às escolas civis.

Entre as invasões francesas e as guerras entre absolutistas e liberais no início do séc. XIX, com destaque para a Revolução Liberal de 1820, as condições das escolas e do ensino em geral deterioraram-se significativamente, acentuando-se o contraste entre o reino e os países além-Pirenéus. De positivo, porém, há a assinalar a extinção do secular Tribunal do Santo Ofício e a abolição da censura pelas Cortes Gerais e Extraordinárias da Nação Portuguesa.

Certo é que nem a primeira arremetida liberal (1820-23) nem a segunda (1834) se revelaram bem-sucedidas na alteração do sistema educativo segundo o ideário liberal burguês, quer por força de grandes constrições financeiras quer por pressões conservadoras. Só o Setembrismo (1836) projetaria e implementaria um novo modelo de ensino condizente com as aspirações político-sociais do liberalismo e que, no fundo, vigorou até 1973. Entre este momento "genesíaco de legislação escolar" (SERRÃO, 1981, p. 27) e o advento da república (1910) assistiu-se a uma torrente normativa consubstanciada em reformas e contrarreformas, ilustradoras das sucessivas conjunturas políticosociais.

Salientemos a reforma de 1836, da autoria de Passos Manuel, responsável por impulsionar o ensino em Portugal, em todos os graus (primário, secundário e superior), moldando-o aos ideais revolucionários liberais. A atividade pedagógica deste ministro responsável pelas políticas educativas foi extensa e metódica, pese embora o facto de apenas ter permanecido no cargo oito meses. Politicamente, surpreende a concentração no Estado de toda a organização escolar, quando o seu antecessor, Rodrigo da Fonseca, determinara que o estabelecimento, manutenção e conservação de todas as escolas primárias eram da responsabilidade dos municípios, que inclusive nomeavam os professores, numa tentativa descentralizadora abandonada nesta legislatura. Realcemos, também, a criação dos Liceus e de outras escolas promotoras do 
ensino técnico e científico, procurando, assim, "implantar uma nova consciência nacional que integrasse o homem português no tipo de sociedade, valorizada pelo trabalho, que a Revolução Francesa e a Revolução Industrial inglesa tinham definido" (CARVALHO, 1986, p. 571).

A reforma geral dos estudos de Passos Manuel, consagrada pelo Decreto de 17 de Novembro de 1836, assume particular importância por estatuir o modelo orgânico de administração das escolas do ensino secundário, constituído pelo conselho do liceu, um órgão colegial integrado por todos os professores, e pelo reitor, um órgão unipessoal assumido pelo professor decano. O Art. $63 .^{\circ}$ institui o conselho do liceu, dependente da Direção Geral dos Estudos, e que trataria de aspetos formais, pedagógicos e científicos da vida de cada escola. Estas atribuições, regulamentadas no Art. $64 .^{\circ}$, denunciam a autonomia conferida a este órgão executivo, já que lhe competia:

$\S 1 .^{\circ}$ - A intendência especial e imediata dos estudos do liceu, em ordem a que cada vez mais se aperfeiçoem, que se observem as leis relativas ao ensino, e que se não introduzam abusos e relaxações que o deteriorem.

§2. ${ }^{\circ}$ A distribuição das disciplinas próprias de cada cadeira, pelas aulas da manhã e da tarde; a designação das aulas, e das horas, o modo dos exercícios literários e dos exames; a abonação das faltas e a habilitação para os exames finais.

$\S 3 .^{\circ}$ - O exame, a escolha e a composição dos compêndios, fazendo sobre isso propostas à Direcção geral dos Estudos, que proporá ao Governo uma recompensa adequada para os autores dos melhores livros elementares.

\$4. ${ }^{\circ} \mathrm{A}$ confecção dos Regulamentos especiais, necessários para a boa ordem, disciplina, e economia do Liceu, e bem assim para o completo desenvolvimento do método de ensino; fazendo convenientes propostas à Direcção geral.

\$5. ${ }^{\circ}$ A aplicação do produto das matrículas, e certidões [...]

§6. ${ }^{\circ}$ Findo o ano lectivo o Conselho enviará à Direcção geral um relatório do estado dos estudos no Liceu, contendo as causas do progresso, ou decadência, e a estatística do estabelecimento. 
Dos artigos transcritos sobressai uma tentativa descentralizadora evidente no poder deliberativo do conselho, responsável, por exemplo, pela observação escrupulosa do cumprimento das leis, pela gestão das receitas, pela organização dos horários ou pela seleção da metodologia, logo, porém, contrariada pelos dois últimos artigos, onde se destaca a necessidade de o conselho ter de fazer chegar as propostas de regulamentos setoriais ou compêndios escolares à Direção Geral de Estudos para aprovação, o que denuncia a centralização vigente, mesmo no período liberal.

Inquestionavelmente, o conselho dos liceus assume-se como o primeiro órgão da escola, quer na direção interna do estabelecimento quer nas relações externas com a Administração Central. Em termos decisórios, determinava-se a "pluralidade absoluta de votos, e em caso de empate, terá o Reitor voto de qualidade" (Art. 65. ${ }^{\circ}$ ). Ao reitor competia-lhe, entre outras tarefas, dar "execução às Leis, aos Regulamentos, e às deliberações do Conselho relativamente ao Estabelecimento de que é Chefe", ou a "inspecção de todo o estabelecimento, com subordinação às deliberações do Conselho", de acordo com o Art. $66^{\circ}$. Constatamos uma hierarquização orgânica com a Administração Central no topo, o conselho do liceu como o principal órgão de direção da escola, com o poder deliberativo, ao qual está subordinado o reitor, como órgão executivo. O modelo descrito manteve-se em vigor durante todo o período liberal, quer no ensino liceal, quer no ensino profissional, aquando da sua criação em 1852.

Outra reforma de fundo da época liberal é a de Costa Cabral, datada de 20 de setembro de 1844, que recria o Conselho Superior de Instrução Pública, estabelecido em Coimbra e composto pelo presidente (o reitor da Universidade), oito vogais ordinários (lentes, professores jubilados ou outros que cumprissem determinados critérios) e vogais extraordinários (professores universitários substitutos e opositores às Cadeiras) sem número fixo. Este órgão dividia-se em dois conselhos: um conselho geral, constituídos por todos os elementos referidos e um conselho ordinário, que apenas excetuava os vogais 
extraordinários, mas que, por sua vez, se subdividia em três secções, relativas a cada grau de ensino: primário, secundário e superior. Ao conselho ordinário competia a direção geral da educação e instrução públicas, mas sem impacto efetivo ao nível da administração das escolas, fruto de constrangimentos políticos e estruturais.

Regulamentam-se, também, algumas alterações nos órgãos diretivos: aquando da reforma de 1836, o reitor era o professor decano do liceu onde exercia funções, enquanto que, com a reforma de 1844, o reitor seria nomeado diretamente pelo Governo, entre os professores do liceu (Art. 78. ${ }^{\circ}$ ), na ausência de Comissários de Estudo4, pois, caso os houvesse, o cargo de reitor ser-lhes-ia atribuído sem intervenção do Governo. O conselho de liceu mantinha a sua constituição, contando com todos os professores, "proprietários" das cadeiras ou "substitutos", e mantinha-se a presidência do reitor. A este cabia, ainda, fiscalizar e inspecionar o ensino particular. A partir desta altura, os conselhos do liceu ganham poderes de decisão quanto à escolha dos compêndios escolares e na organização das estruturas de instrução e avaliação que não estão sob alçada da Administração Central, como anteriormente. Este regime manteve-se inalterável nas reformas seguintes, até à alteração sofrida com a reforma de 1895.

A partir de 1851, o país entra num período mais estável com o fim das guerras civis e o advento do período commumente designado por Regeneração. Nesta época destaca-se, claramente, Fontes Pereira de Melo, cuja contribuição mais notável no ensino é a legislação sobre Escolas Técnicas (industriais, comerciais e agrícolas). A instabilidade no ensino, porém, é visível, pois, entre 1851 e 1859, observam-se três alterações aos regulamentos dos Liceus, justificadas pelas particularidades ideológicas dos políticos que se revezavam na cadeira do poder.

4 Os Comissários de Estudos representavam um órgão intermédio, entre as escolas e a Administração Central, regulamentado pelo Art. $161 .^{\circ}$ da reforma de 1844 , e tinham a seu cargo funções de inspeção pedagógica e disciplinar sobre todos as escolas da sua área geográfica (FERNANDES, 1992). 
Assinalemos a Lei de 7 de junho de 1859 que extingue o Conselho Superior de Instrução Pública, sediado em Coimbra, substituindo-o pela Direção-Geral de Instrução Pública e o Conselho Geral de Instrução Pública, afetos ao Ministério do Reino. Esta reorganização da administração dos ensinos primário, secundário, liceal e superior marca o fim do poder partilhado na direção da instrução pública entre o Governo central e a Universidade de Coimbra.

A reforma de 1860 altera significativamente a hierarquia interna das escolas. Ao conselho escolar são retirados os poderes de decisão científica e pedagógica (evidente na seleção dos compêndios, na organização da instrução ou da avaliação), transferidos para a Administração Central. Também os poderes de inspeção são transferidos para o reitor, que teria sob sua alçada todo o corpo docente e não docente, senda ainda da sua responsabilidade a elaboração dos relatórios anuais, anterior competência do Conselho. Este órgão conserva, ainda assim, as funções executivas relativas à organização dos horários, do serviço de exames ou a distribuição do serviço docente (Art. 87. ${ }^{\circ}$ ). Mantém-se também como um órgão consultivo quanto à seleção dos compêndios escolares e a elaboração dos "pontos de exame" (Art. 88. ${ }^{\circ}, 2^{\circ}$ ), ambos carecendo de aprovação do Conselho Superior de Instrução Pública.

Prova da turbulência política durante a monarquia constitucional são as reformas de vulto no ensino, datadas de 1870, 1872 e 1878. Na primeira é criado o Ministério dos Negócios da Instrução Pública, no fundo, uma Secretaria de Estado, substituindo, pelo menos em nome, a Direção-Geral da Instrução Pública que fazia parte do Ministério do Reino, com o ministro D. António da Costa a implementar uma reforma sentida particularmente no ensino primário. Assinalemos que os encargos com as escolas espalhadas pelo país eram da responsabilidade das Câmaras Municipais e das Juntas Gerais de Distrito, sendo as verbas necessárias para o seu funcionamento descritas no Decreto de 16 de agosto de 1870. Nas seguintes, da responsabilidade de Rodrigues Sampaio, destaquemos a de 1872, já que o enfoque se faz sentir particularmente no ensino 
liceal e na descentralização do ensino. Se nos surpreendemos com o curtíssimo intervalo de tempo nas reformas dos anos 70, que dizer das três reformas de vulto ocorridas no ensino em 1880, 1886 e 1888 ? Não sendo estas suficientes para implementar a visão dos seus mentores, em 1890, novos diplomas reformadores saem da forja governamental, criando, pela segunda-vez, o Ministério da Instrução Pública, adotando a designação de Ministério da Instrução Pública e Belas Artes. Em 1894, com a ditadura de João Franco e com as Cortes encerradas, regressa-se à centralização do ensino, justificada como uma necessidade, como se observa no preâmbulo do Decreto de 22 de dezembro:

a eficácia do auxílio que ao Estado pode e deve ser dado pelas corporações administrativas e pela iniciativa individual no interesse máximo da educação popular, julgou contudo o Governo que deveria continuar reservada para o poder central a principal parte de acção, convencido como está de que no estado actual dos costumes do país seria ainda prejudicial à mais rápida e tão urgente difusão dos conhecimentos mais rudimentares a repetição da generosa tentativa de 1878.

Este Decreto, normalmente referenciado como a "Reforma de Jaime Moniz", autor do projeto que reformularia o ensino secundário bebendo inspiração no ensino secundário alemão, consubstanciou-se numa reforma "solidamente apoiada num estudo amplo, demorado e minucioso, com firmeza e determinação" (CARVALHO, 1986, p. 630). Neste sentido, surge, ainda, o Regulamento Geral do Ensino Secundário, de 14 de agosto de 1895, que, nos seus 225 artigos, se caracteriza, do ponto de vista formal e legal, por: (i) regulamentar minuciosamente as tarefas e deveres dos professores responsáveis pelos diferentes cargos; (ii) criar uma estrutura hierárquica para exercício do poder de decisão e controlo assente no reitor e seus auxiliares; (iii) diminuir a autonomia dos professores, subordinados às decisões do Conselho e à fiscalização das autoridades do Liceu. O Art. 128. ${ }^{\circ}$ esclarece que o reitor "é o chefe do liceu”, expressão usada pela primeira vez em 1836 e que se manterá até 
1936, ano em que se determina que a "direcção do Liceu pertence ao Reitor" (Art. 25. ${ }^{\circ}$ do Decreto-Lei n. ${ }^{\circ} 27$ o84, de 14 de outubro). O processo de nomeação do reitor retoma o estatuído pelo Decreto de 14 de junho de 1880, já que seria nomeado pelo governo, mas entre professores do ensino secundário, ensino superior ou mesmo entre outros docentes, desde que habilitados com curso superior. No fundo, o reitor emergia como mais um órgão da Administração Central que, deste modo, se torna presente na gestão direta dos liceus. O Art. $128 .^{\circ}$ acrescentava, ainda, que a nomeação era em comissão de serviço e o reitor não poderia pertencer ao corpo docente do liceu que iria dirigir, um regime que permitia, a qualquer momento, a sua destituição por decisão discricionária do poder central.

Perante este quadro legal, assiste-se a um procedimento de cariz iminentemente político, em detrimento do usual caráter administrativo e burocrático, já que

\footnotetext{
A dependência política e não apenas administrativa passa agora a caracterizar o exercício destas funções e nessa medida a subordinação hierárquica do reitor respeita não apenas ao cumprimento das leis, regulamentos e ordens superiores que definem a relação hierárquica entre funcionários de uma administração centralizada mas também à orientação política definida pelo governo no exercício das suas funções de direcção (FERNANDES, 1992, p. 245).
}

Atentemos, também, na evolução das funções de inspeção do reitor, durante o séc. XIX. Em 1836, determinou-se que a função de inspeção do reitor estava subordinada ao poder de inspeção do conselho de liceu, sendo este o responsável pela elaboração dos relatórios anuais. A reforma do ensino liceal de 1860 regulamenta novas atribuições ao reitor, responsável, então, pela inspeção que recaía sobre todos os funcionários e estabelecimentos do liceu, bem como pela elaboração dos relatórios (Art. 99. ${ }^{\circ}$ ); na reforma de 1873, as funções inspetivas alargam-se ao cumprimento dos programas e ao cumprimento das normas legais pelo corpo docente e não docente (Art. $94 .^{\circ}$ ); no já mencionado 
Regulamento Geral do Ensino Secundário de 1895, da responsabilidade de João Franco, as suas atribuições inspetivas são expostas de forma mais clara. Assim, fazem parte das suas incumbências:

fiscalizar o cumprimento de todas as normas e regulamentos por parte dos professores e funcionários (Art. 129..$^{\circ}$, números $2 .^{\circ}, 4 .^{\circ}$ e $14 .^{\circ}$ );

inspecionar todo o processo de instrução, garantindo a rigorosa observância do plano de ensino, de acordo com as normas vigentes (Art. 129..$^{\circ}$, número $4 .^{\circ}$ ) e tomando conhecimento de todos os trabalhos escritos e notas de frequência atribuídas aos alunos servindo de elo de ligação com as famílias (Art. $129 .^{\circ}$, número $100^{\circ}$ );

fiscalizar as reuniões do Conselho Escolar quanto à sua legalidade e quanto ao seu conteúdo podendo suspendê-las quando delas discordar (Art. 129. ${ }^{\circ}$, número $17 .^{\circ}$ ).

participar ao Diretor Geral de Instrução Pública qualquer infração detetada, que mereça o conhecimento da "autoridade superior" (Art. $129 .^{\circ}$, número $14 .^{\circ}$ ).

O reitor foi ganhando autonomia e poder face aos restantes agentes educativos internos, particularmente quando se sobrepõe ao conselho escolar na hierarquia do Liceu, estando apenas subordinado à Administração Central. Esta subordinação, porém, acentua-se com a reforma de 1895, quando se acrescenta às atribuições do reitor, de forma explícita, a execução das ordens do Governo (Art. 129. ${ }^{\circ}$, número $17 .^{\circ}$ ).

O reitor vê o seu poder executivo aumentado com a transferência de competências de caráter pedagógico, organizacional e de avaliação, anteriormente da responsabilidade do conselho escolar. Exemplifiquemos com a distribuição do serviço docente, organização de horários e do serviço de exames "ouvido o Conselho Escolar" (Art. 59..$^{\circ}$, \$1. ${ }^{\circ}$ ). O decreto restringe a participação neste órgão apenas aos professores efetivos (Art. 122. ${ }^{\circ}$ ). As decisões são tomadas "em votação nominal pela maioria do número legal dos professores" com assento, sendo que o presidente só vota em caso de empate (Art. $123 \cdot{ }^{\circ}$ ). O conselho escolar transforma-se num órgão de natureza consultiva 
ao serviço do reitor, que o pode convocar extraordinariamente quando entender, já que as reuniões ordinárias são convocadas superiormente pelo regulamento em apreço (Art. 126. ${ }^{\circ}$ ). Nesta altura, já não se coloca a questão da seleção dos compêndios, anterior competência do conselho, pois, entretanto, instituíra-se o livro único (Art. 26. ${ }^{\circ}$ do Decreto de 22 de dezembro de 1894). Ao conselho escolar resta-lhe, assim, a aprovação dos pontos de exame aprovados pelo júri (Art. $65^{\circ}$ ), a distribuição do serviço de exames e a marcação do horário de prestação de provas (Art. 126. ${ }^{\circ}$ ). As alterações introduzidas pela reforma de 1895 representam uma subalternização inequívoca do conselho ao reitor, que emerge como o órgão executivo e fiscalizador de toda a ação pedagógica, tal como atestam as palavras proferidas por Fernandes quando escreve que

\begin{abstract}
A inversão da hierarquia dos órgãos liceais ocorrida no período iniciado em 1860 é uma consequência da centralização científica e pedagógica reforçada neste período. Daí que ela expresse não uma transferência de poderes de decisão do Conselho Escolar para o Reitor, mas essencialmente, uma transferência de poderes do Liceu para a Administração Central. É em consequência do esvaziamento de poderes sofrido pelo Conselho Escolar e como resultado dessa transferência que o Reitor emerge como o órgão hierárquico do Liceu (1992, p. 279).
\end{abstract}

Se considerarmos que a centralização da educação é um fenómeno que tem início com a reforma pombalina, com o Estado a chamar a si toda a responsabilidade educativa, afastando outros agentes tradicionalmente afetos ao ensino, podemos concluir que aquela continua e se reforça durante o período liberal, afastando-se da tríade revolucionária da Liberdade, Igualdade e Fraternidade, facto justificável por singularidades e idiossincrasias bem nacionais. Certo é que

entre nós, sempre aconteceu que tais ímpetos de avanço político e educativo acabaram por inscrever-se numa prática educativa morosa, inçada de dificuldades de toda a ordem, desde as financeiras, resultantes da penúria do estado, até às culturais, oriundas do nível 
científico-pedagógico dos agentes de ensino recrutados ou recrutáveis (SERRÃO, 1981, p. 23).

De qualquer modo, apesar da turbulência normativa e das dificuldades na aplicação do novo sistema de ensino forjado no clamor burguês liberal é, inquestionavelmente, a partir deste século que as escolas se assumem como unidades administrativas locais bem definidas quanto ao seu âmbito territorial e quanto aos seus órgãos de gestão (FERNANDES, 1992).

Consciente das dificuldades sentidas pelo reino no início do séc. $\mathrm{XX}$, o Governo, presidido por Hintze Ribeiro, prosseguiu o afã legislativo, desejoso de mostrar a sua vitalidade e a sua capacidade de resolver a precariedade institucional, motivada pela descrença na monarquia visivelmente esgotada. Em 1901, destaquemos a reorganização da Direção Geral da Instrução Pública e, em 1905, a reforma do ensino secundário pelo então ministro do Reino, Eduardo José Coelho. A 19 de agosto de 1907, a reforma abrange todos os serviços do ensino, começando pela parte diretiva, sobre a qual mencionaremos apenas a reorganização do Conselho Superior de Instrução Pública, com divisões em duas Direções-Gerais, uma afeta ao ensino primário e outra para os restantes graus de ensino.

\section{TENTATIVAS DE DESCENTRALIZAÇÃO DURANTE A I REPÚBLICA - ALTERNÂNCIA DE PODER ENTRE $O$ REITOR E O CONSELHO ESCOLAR (1911-1926)}

O ímpeto reformador caracterizador do período liberal e, mais tarde ditatorial, continuou no período republicano. Os legisladores apontaram como problemas a solucionar o "analfabetismo, o insuficiente número de escolas primárias, a deficiente preparação pedagógica e científica dos professores desse mesmo grau de ensino e a sua mísera situação económica" (CARVALHO, 1986, p. 656). Acresciam barreiras que impediam a modernização das práticas 
pedagógicas segundo os ideais revolucionários, como a presença das Ordens Religiosas, a doutrinação católica nas escolas do Estado e os privilégios da Universidade de Coimbra. Pedagogos como João de Barros defendem um método educativo de cariz nacionalista, valorizando a Pátria e a República. Assim, regulamentam-se formas especiais de educação cívica no ensino liceal, procurando "uma doutrinação direta dos valores éticos e cívicos republicanos, através dos currículos, da acção pedagógica docente e das actividades educativas extracurriculares promovidas pela escola" (FERNANDES, 1992, p. 385).

Entretanto, os assuntos do ensino, à época sem ministério próprio, emanavam, com o Governo Provisório da República, de um novo ministério, o Ministério do Interior, mas a ação de outros ministros refletia-se também no ensino. Por exemplo, proveniente do Ministério da Justiça temos o Decreto de 31 de Dezembro de 1910, que, no seu artigo $40 .^{\circ}$, determina o afastamento completo e compulsivo de todas as organizações religiosas do ensino, em particular da Companhia de Jesus, que a pouco e pouco se havia infiltrado novamente no reino:

Os membros das associações religiosas a que se refere o artigo $6 .^{\circ} \mathrm{e}$ seus parágrafos do decreto de 8 de Outubro de 1910, e que foram autorizados a viver em Portugal em vida secular, não poderão exercer o ensino ou intervir na educação, quer como professores quer como empregados, quer como directores ou administradores de quaisquer institutos ou estabelecimentos de ensino, seja directamente, seja por interposta pessoa.

O Ministério da Instrução Pública seria criado, pela terceira vez na História de Portugal, por lei de 7 de julho de 1913, agora de forma permanente.

Relativamente à administração escolar, recuemos a 1910, quando o Decreto do Governo provisório de 17 de outubro introduziu uma alteração na designação dos reitores dos Liceus, que passaram a ser eleitos pelo conselho escolar, sendo condição obrigatória fazer parte do quadro do Liceu. Para tomar consciência da "revolução" administrativa, recordemos que, em 1836, o reitor 
era o professor decano em exercício de cada liceu e, em 1844, era designado por nomeação do Governo. O processo eleitoral afigura-se como uma forma de designação de cargos políticos distinguindo-se, claramente, do processo de nomeação burocrática, provocando diferentes relações de poder no interior da organização. No processo burocrático, a nomeação decorre de concurso ou nomeação de acordo com certificados comprovativos da qualificação profissional para o cargo, já a eleição ou a nomeação direta do titular de um cargo por uma entidade superior pressupõe considerandos assentes na confiança depositada no indivíduo que se apresenta como capaz de realizar as finalidades educativas delineadas, independentemente das suas qualificações profissionais. Ao optar pelo processo eleitoral atribui-se uma dimensão política ao cargo reitoral, certamente resultante das funções políticas atribuídas ao ensino liceal na formação dos cidadãos com responsabilidades dirigentes no futuro. Acrescia o incremento do pendor democrático e da tendência descentralizadora, já antes tentada.

\footnotetext{
A eleição introduzia, porém, o princípio democrático de participação, com força vinculativa, na designação dos reitores. Nesta medida ela descentralizava a distribuição do poder, quebrava o princípio da dependência hierárquica dos órgãos liceais em relação à Administração Central e invertia as relações hierárquicas internas dos órgãos liceais subordinando o Reitor ao Conselho Escolar (FERNANDES, 1992, p. 405).
}

Com renovadas esperanças de modificar mentalidades e garantir repercussões do ensino no desenvolvimento económico-social do país, os legisladores republicanos mantiveram uma prolífica ação reformadora, da qual destacaremos a divisão dos encargos com a instrução primária entre o Estado e as Câmaras Municipais, numa tentativa descentralizadora, antes defendida por Alexandre Herculano. Todavia, este desiderato dos republicanos não correu da melhor forma, por um lado, pela impossibilidade financeira de as autarquias assumirem os seus compromissos, por outro, pela manifesta falta de vontade de o fazerem. A iniciativa descentralizadora interromper-se-ia em 1918, assistindo- 
se a um novo sistema em 1919, com a criação de Juntas Escolares, organismos que rapidamente desiludiram, como o comprova um Decreto de 12 de Maio de 1922, cujo preâmbulo aponta para os constrangimentos sentidos, podendo-se ler que

\footnotetext{
Considerando que algumas Juntas Escolares não cumprindo com a sua missão têm cometido as maiores ilegalidades;

Considerando que em alguns concelhos estão de tal forma divididas e os seus membros tão incompatibilizados, que a sua existência só prejudica a boa administração do ensino;

[...] Considerando, enfim, que se torna indispensável regular devidamente o seu funcionamento, para que não aumente o caos na administração do ensino, que em alguns concelhos já existe.
}

Durante este período observam-se outras tentativas de descentralização, desburocratização e flexibilização do ensino. $\mathrm{Na}$ estrutura de gestão, um dos contributos mais relevantes terá sido a criação de um nível intermédio de gestão pedagógica, regulamentado pelo Decreto n. ${ }^{\circ} 503$ de 21 de Maio de 1914. Implementam-se três órgãos especializados para o planejamento e coordenação das atividades pedagógicas: o conselho de professores de disciplina ou grupo disciplinar (assegurava a coordenação vertical do ensino na mesma área disciplinar), o conselho de classe (assegurava a coordenação horizontal do ensino das várias disciplinas, sob a presidência do diretor de classe) e o conselho de diretores de classe (estabelecia a coordenação global de todas as atividades pedagógicas, sob a presidência do reitor).

Referência obrigatória é o Decreto n. ${ }^{0} 503$ de 21 de Maio de 1914, da iniciativa do ministro da Instrução José de Matos Sobral Cid, que apresenta como lema no seu Preâmbulo "menos burocracia e mais pedagogia", alargando no seu articulado as competências pedagógicas e administrativas do reitor. Assim se explica a nova política republicana: 
[...] fazer dos reitores dos liceus simples executores das determinações ministeriais, coartar-lhes os meios de execução, não lhes facultando os elementos próprios para se afirmarem como homens de iniciativa, o mesmo é que privar esses organismos da força propulsora indispensável ao seu progresso a apropriada adaptação.

Daqui deriva, naturalmente, a necessidade de conferir aos reitores as mais amplas atribuições e os precisos meios de acção, sabido como é, pelo simples exame dos factos, que um bom reitor é quem, em regra, faz um bom liceu.

Dizer que o reitor é o chefe da casa, de nada serve desde que se lhe não dêem atribuições correspondentes e em relação com aquele princípio, de sorte a conceder-se livre desenvolvimento ao exercício do seu coeficiente individual e pedagógico (Preâmbulo do Decreto n. ${ }^{\circ}$ 503, de 20 de maio de 1914).

Apresentado como "a primeira autoridade do liceu", estabelecendo a ponte entre o Ministro de Instrução Pública e o conselho escolar (Art. 1. ${ }^{\circ}$ ), compete ao reitor a direção pedagógica, administrativa e financeira do estabelecimento que dirige, beneficiando, inclusive, de relativa autonomia científica, por exemplo, o Art $3 .^{\circ}$ determina que os programas do ensino liceal sejam meramente indicativos. Desta forma, no início do ano letivo, o reitor reuniria com os docentes de cada grupo disciplinar e, a partir do programa oficial, selecionariam os itens a serem lecionados. Em consequência, é possível observar alguma diversificação curricular, restringida apenas à gestão dos conteúdos programáticos oficiais e à supervisão do reitor. A sua ascendência relativamente ao conselho escolar também é notória, quando se regulamenta que em caso de divergência irredutível entre os dois órgãos, o differendum seria submetido à apreciação do Ministério, mas, no período de espera, prevaleceriam as propostas reitorais (Art. ${ }^{\circ} 4$, §único).

Quanto aos órgãos intermédios de gestão pedagógicos - conselho de diretor de classe, conselho de grupo e conselho de classe - revestem-se de caráter consultivo. No fundo, a sua intervenção limitava-se ao início do ano letivo no assessoramento ao reitor na organização de horários, distribuição de serviço docente (conselho de diretores de classe) e estabelecimento de conteúdos programáticos (conselho de grupo), verificando-se um esvaziamento 
de funções durante o ano letivo. Daqui se conclui que, durante este breve período temporal, o reitor era o órgão máximo na linha de comando interna, exercendo o seu poder sobre os órgãos colegiais e sobre professores, funcionários e alunos.

A retificação do Decreto n. $^{0} 503$ atribuiria, porém, mais autonomia e poder ao conselho escolar a quem o reitor passaria a estar subordinado, já que, além de eleger o reitor, intervinha na aprovação das suas propostas no que concerne a aprovação de programas, compêndios, organização de horários, distribuição de serviço e outras atividades educativas (Art. $5 \cdot^{\circ}$, §único).

Todavia, o regulamento de 1917 não daria seguimento a esta disposição, o que comprova que, as reformas republicanas, apesar de alguma flexibilidade inicial em determinadas áreas do ensino, regressam ao modelo uniformizado e centralizado dos governos liberais (FERNANDES, 1992).

Em 1918, pelo Decreto n. ${ }^{\circ}$ 3767, de 5 de janeiro, durante o regime ditatorial de Sidónio Pais, altera-se novamente o processo de designação dos reitores, podendo o governo nomear interinamente para o cargo de reitor indivíduos externos aos quadros dos estabelecimentos de ensino (Art. 1. ${ }^{\circ}$ ). Este normativo justifica a alteração pela necessidade de "colocar na direcção de alguns estabelecimentos dependentes do Ministério de Instrucção Pública delegados de confiança do Governo", o que se configura como uma medida de caráter político, visando a prossecução nas escolas de orientações governamentais ao invés de outras decididas localmente, a nível interno. É, porém, a reforma liceal do mesmo ano que regulamenta, pormenorizadamente, quer o processo de designação quer as competências dos órgãos de gestão escolares. Coexistem duas formas: (i) o reitor é nomeado pelo Governo, de entre os professores do ensino superior; (ii) o reitor é eleito pelo conselho escolar, eleição feita em lista tríplice de professores efetivos do respetivo liceu (Art. $347^{\circ}$ ). Denota-se, ainda, alguma arbitrariedade no ponto seguinte, quando se enuncia que o Governo poderá mandar repetir a eleição "sempre que o julgue conveniente" $\left(\S 1 .^{\circ}\right)$. O mandato tinha a duração de quatro anos, podendo ser 
reeleito quando professor do liceu ou reconduzido quando professor do ensino superior $\left(\S 2 .^{\circ}\right)$. Desta forma, o Governo tinha o papel decisivo, já que escolhia o processo de designação e, em caso de eleição, cabia-lhe selecionar o docente indicado na lista apresentada pelo conselho escolar.

Relativamente às competências do reitor reduzem-se à execução das diretrizes emanadas do conselho escolar (Art. $351 .^{\circ}$, ponto $22 .^{\circ}$ ), que se mantinha restrito aos professores efetivos. $O$ conselho ressurge como o órgão máximo da escola, responsável pela nomeação e designação de professores para todos os cargos de gestão intermédia, pelas propostas de nomeação de pessoal não docente, pela fixação do número de professores agregados a nomear para cada grupo, pela seleção de livros escolares, pela distribuição de serviço e do horário ou pela votação do orçamento do Liceu e apreciação das contas apresentadas pelo conselho administrativo (Art. $365^{\circ}{ }^{\circ}$.

Após a queda de Sidónio Pais, já num governo de base parlamentar, o Governo abole o processo eleitoral, determinando que "Os reitores das Universidades e dos Liceus e os directores dos outros estabelecimentos de ensino a cargo do Estado são de nomeação do Governo" (Art. 1. ${ }^{\circ}$, Lei n. ${ }^{\circ}$ 861, de 27 de agosto de 1919).

A reforma de 1921 veio acrescentar mais peso decisório à Administração Central, já que, para a nomeação do reitor, se alargava o universo a todos os professores efetivos dos quadros liceais e não apenas ao quadro do estabelecimento de ensino para o qual era nomeado (Art. 308. ${ }^{\circ}$ ), comprovando a escolha baseada em critérios ideológicos e políticos em detrimento do valor profissional reconhecido interpares. Assim,

Estas disposições legais demonstram como na definição do perfil do professor idóneo para exercer o cargo de Reitor o critério da confiança política do Governo predominava sobre outros critérios baseados no seu perfil pedagógico, na confiança manifestada pelo corpo docente do liceu que ia dirigir ou nas suas capacidades de liderança da comunidade liceal, pressupostos no sistema eleitoral de 1910 (FERNANDES, 1992, p. 412). 
Desta forma, concluímos que, apesar das influências da "escola nova" e da vontade de renovação pedagógica manifestada pelos reformadores republicanos, as suas políticas acentuaram a centralização iniciada no período liberal, exemplificadas com a nomeação direta dos agentes educativos, do diretor de classe ao presidente do Júri de Exames, passando, obviamente, pelo reitor. Encerra-se, assim, a experiência de descentralização iniciada em 1910, o que se explica pela impossibilidade de manter em simultâneo a descentralização pedagógica e o controlo político e administração centralizada de que a I República não abdicou. Ainda assim, subjacente às reformas republicanas observa-se uma conceção de democratização do ensino mais abrangente do que no período liberal, particularmente no que se refere aos órgãos de gestão intermédia.

\section{CONCLUSÃO}

Nesta breve incursão diacrónica, seguindo o rumo de pedagogos e políticos, numa abordagem nitidamente legalista e normativa, foi possível percecionar as diferentes políticas educativas que enformaram o modelo de gestão educativo português durante os Descobrimentos até à $1^{\mathrm{a}}$ República.

Este trajeto, com enfoque nas questões do ensino e na administração e gestão das escolas, permite-nos concluir que à educação pública foi sendo atribuída uma importância crescente, quer pelo impacto fulcral que esta desempenha no avanço tecnológico e económico do país, quer por representar um veículo de imposição ideológica, transformando-se, assim, num instrumento de poder que poucos se coibiram de usar.

Comprovámos a importância da Igreja e dos seus agentes na transmissão da cultura e do saber até ao séc. XVIII, altura em que se interrompe o monopólio clerical da educação pública e se inicia a laicização do ensino, com o Estado a assumir um papel determinante na criação e um sistema educativo 
progressivamente democrático e igualitário, "O surgimento e desenvolvimento da escola pública representa uma vitória do Estado sobre outras instituições a que teve de opôr-se para garantir o controlo sobre a educação, e o monopólio da educação que o estado hoje detém, pelo menos em termos de controlo, foi conquistado em boa parte ao ensino doméstico e ao ensino promovido pela Igreja” (LIMA, 1998, p. 41-42).

Efetivamente, o modelo político e organizacional da escola esteve durante décadas desprovido de quaisquer estruturas democráticas e participativas, salientando-se a figura do reitor/diretor funcionando como um representante do poder central, um delegado de confiança política junto de cada escola.

As sucessivas políticas educativas evidenciaram tímidas iniciativas de descentralização, desburocratização e flexibilização do ensino, com destaque para as medidas da I República, mas sem impacto real no futuro dos estabelecimentos de ensino pelos retrocessos imediatos.

\section{REFERÊNCIAS}

Alvará Régio de 17 de agosto de 1758.

Alvará Régio de 28 de junho de 1759.

Carta Régia de 6 de julho de 1759.

Carta de Lei de 6 de novembro de 1772.

Carta Régia de 17 de dezembro de 1794.

CARVALHO, Rómulo. História do Ensino em Portugal. Desde a fundação da nacionalidade até o fim do regime de Salazar-Caetano. Lisboa: Fundação Calouste Gulbenkian, 1986.

CISCAR, Concepción; URIA, María Esther. Organización escolar y acción directiva. Madrid: Narcea Ediciones, 1988. 
Decreto de 17 de novembro de 1836.

Decreto de 22 de dezembro de 1894.

Decreto de 31 de dezembro de 1910.

Decreto n. ${ }^{\circ} 503$, de 21 de maio de 1914.

Decreto n. ${ }^{\circ} 8$ 140, de 22 de maio de 1922.

FERNANDES, António Sousa. A centralização burocrática do Ensino

Secundário: evolução do sistema educativo português durante os períodos liberal e republicano (1836-1926). 1992. Tese (Doutoramento) - Universidade do Minho, Braga, 1992.

GOMES, Joaquim Ferreira. O Marquês de Pombal e as Reformas do Ensino. 2. ed., Pedagogia - 8. Coimbra: Instituto Nacional de Investigação Científica, 1989.

\section{LIMA, Licínio. A escola como organização e a participação na} organização escolar. Um estudo da Escola Secundária em Portugal (19741988). 2. ed. Braga: Universidade do Minho, 1998.

MARQUES, António Henrique Oliveira. História de Portugal. v. I, 8. ed. Lisboa: Palas Editores, 1980.

SERRÃO, Joel. Estrutura social, ideologias e sistema de ensino. In: SILVA, Manuela; TAMEN, Maria Isabel (Org.). Sistema de ensino em Portugal. Lisboa: Fundação Gulbenkian, 1981.

MARIA JOÃO DE CARVALHO é professora auxiliar da Universidade de Trásos-Montes e Alto Douro (Utad). Doutorada em Educação/área de especialização em Organização e Administração Escolar. Investigadora Integrada no Centro de Investigação e Intervenção Educativas (Ciie) da Faculdade de Psicologia e de Ciências da Educação da Universidade do Porto e Investigadora Colaboradora do Centro Interdisciplinar de Ciências Sociais e Humanas (CICS.Nova) da Universidade Nova de Lisboa e do Centro de Investigação em Educação (CIEd) da Universidade do Minho. Diretora do Doutoramento em Ciências da Educação e do Mestrado em Ciências da Educação: área de especialização em Administração Educacional da Utad. É Avaliadora Externa de Escolas desde 2010.

E-mail: mjcc@utad.pt

(ib) http://orcid.org/0000-0002-6870-849x 
TERESA SOARES é Mestre em Ciências da Educação na área de especialização de Administração Educacional, professora do ensino secundário no Agrupamento de Escolas Dr. João de Araújo Correia, em Peso da Régua. Ao longo da sua carreira desempenhou várias funções na administração e gestão escolar como assessora da direção, membro do Conselho Geral, do Conselho Pedagógico e Coordenadora de Departamento. É formadora do Conselho Científico-Pedagógico da Formação Contínua. Recebeu em 2012/13 o Prémio Bes de Excelência.

E-mail: teresa.pro@gmail.com

(1) http://orcid.org/0000-0002-0501-516X

Recebido em: 05 de fevereiro de 2018

Aprovado em: 06 de maio de 2019

Revista História da Educação - RHE

Associação Sul-Rio-Grandense de Pesquisadores em História da Educação - Asphe Artigo de acesso aberto distribuído nos termos de licença Creative Commons. 